\title{
Biomaterial-mediated modification of the local inflammatory environment
}

\author{
Shane Browne and Abhay Pandit* \\ Network of Excellence for Functional Biomaterials (NFB), National University of Ireland, Galway, Ireland
}

Inflammation plays a major role in the rejection of biomaterial implants. In addition, despite playing an important role in the early stages of wound healing, dysregulated inflammation has a negative impact on the wound healing processes. Thus, strategies to modulate excessive inflammation are needed. Through the use of biomaterials to control the release of anti-inflammatory therapeutics, increased control over inflammation is possible in a range of pathological conditions. However, the choice of biomaterial (natural or synthetic), and the form it takes (solid, hydrogel, or micro/nanoparticle) is dependent on both the cause and tissue location of inflammation. These considerations also influence the nature of the anti-inflammatory therapeutic that is incorporated into the biomaterial to be delivered. In this report, the range of biomaterials and anti-inflammatory therapeutics that have been combined will be discussed, as well as the functional benefit observed.

Edited by:

Gilson Khang,

Chonbuk National University, South Korea

Reviewed by: Mikaël M. Martino, Osaka University, Japan Elizabeth R. Balmayor,

Technical University Munich, Germany

*Correspondence: Abhay Pandit,

Network of Excellence for Functional Biomaterials (NFB), Biosciences, National University of Ireland, Galway,

Ireland

abhay.pandit@nuigalway.ie

Specialty section:

This article was submitted to Tissue Engineering and Regenerative

Medicine, a section of the journal

Frontiers in Bioengineering and Biotechnology

Received: 07 March 2015 Accepted: 30 April 2015

Published: 15 May 2015

Citation:

Browne S and Pandit A (2015) Biomaterial-mediated modification of the local inflammatory environment.

Front. Bioeng. Biotechnol. 3:67. doi: 10.3389/fbioe.2015.00067
Furthermore, we point toward future strategies in the field that will bring more efficacious anti-inflammatory therapeutics closer to realization.

\section{Keywords: biomaterials, foreign body response, inflammation, drug delivery, controlled release}

\section{Introduction}

The inflammatory response is an essential part of the healing process (Martin and Leibovich, 2005; Li et al., 2007). Inflammation is initiated by necrosis and tissue injury, through the recognition of damage associated molecular patterns (DAMPs). DAMPs that trigger inflammation include intracellular proteins and nucleic acids released by dying cells, and extracellular matrix (ECM) fragments such as low molecular weight hyaluronic acid (HA) (Kataoka et al., 2014). In addition, stores of inflammatory cytokines including IL-1 $\alpha$ and IL-33 present in cells are released following necrotic cell death (Chen and Nunez, 2010). Inflammation is required to remove necrotic and apoptotic cells, cleaved ECM molecules, and to initiate subsequent angiogenesis and tissue repair (Jiang and Liao, 2010). In fact, inflammatory cells have been shown to play a role in regeneration (Kim et al., 2013). However, excessive and chronic inflammation leads to the formation of a hostile environment for regeneration and repair, resulting in further cell death. Excessive inflammation and ECM remodeling lead to the formation of a fibrotic scar through the upregulation of matrix metalloproteinases (MMPs) and increased deposition of collagen type I and III (Dobaczewski and Frangogiannis, 2008). This is typically characterized by increased neutrophils infiltration and pro-inflammatory macrophage retention. This amplifies the pro-inflammatory cytokine response, along with MMP activity and the presence of radical oxygen species (ROS). It has been shown that improved wound healing occurs following a lesser inflammatory response in fetal wound healing (Redd et al., 2004), with a reduced expression of pro-inflammatory cytokines, transforming growth factor-beta (TGF- $\beta$ ), and overexpression of interleukin-10 (IL-10) (Lo et al., 2012). A similar effect has been observed in fetal myocardium, with reduced inflammation allowing for complete functional restoration (Herdrich et al., 2010). Furthermore, reduction in inflammation has been 
shown to promote mesenchymal stem cell (MSC)-mediated bone tissue regeneration (Liu et al., 2011; Chang et al., 2013). While scarless healing cannot be completely attributed to the absence of inflammation, it does present evidence that a reduced inflammatory response can result in a more favorable outcome.

Thus, strategies to reduce inflammation can prove to be of benefit to treat conditions in which excessive inflammation causes damage to the tissue, or when inflammation becomes chronic.

\section{Biomaterials to Modulate Inflammation}

Implanted biomaterials can cause an inflammatory response, with the level of this response dependent on the material of choice along with the site in the body into which it is implanted (Luttikhuizen et al., 2006a,b; Anderson et al., 2008). This is known as the foreign body response (FBR) and is the response of the host to the implant. Following implantation, a biomaterial acquires a layer of host proteins that is associated with the surface chemistry of the material. This occurs before any interaction with host cells, and governs the type of cells that interact and their phenotypes. Material properties and, particularly, surface chemistry have an effect on protein deposition on the surface. The proteins that typically absorb on the surface include fibrinogen, albumin, and fibronectin. These proteins form a provisional matrix composed mostly of fibrin around the implant. This matrix acts like a thrombus and initiates a wound healing-like inflammatory response. Inflammatory cells such as neutrophils and macrophages are attracted by the buildup of chemokines and other chemoattractants in the provisional matrix. Therefore, the choice of biomaterial is of the utmost importance, with an obvious preference for materials that cause a minimal acute response. Typically, anti-inflammatory strategies using biomaterials have involved loading of therapeutics into biomaterial systems, with therapeutic release in vivo aiding to alleviate inflammation. These anti-inflammatory signals are composed of anti-inflammatory drugs, proteins, or nucleic acids, while the delivery of stem cells has also been shown to result in a reduced inflammatory response. In addition, a number of naturally occurring biomaterials have intrinsic anti-inflammatory signals. These include high molecular weight HA (Nakamura et al., 2004; Hirabara et al., 2013) and chitosan, which have ROSscavenging properties (Je and Kim, 2006). However, in the case of most materials, loading of anti-inflammatory therapeutics is necessary to modulate the inflammatory microenvironment.

A wide variety of therapies to reduce inflammation exist, from gene therapy to receptor blocking antibodies, protein delivery, and cell therapy (see Figure 1B). However, as yet, no outstanding candidate has emerged that can convincingly reduce inflammation in all situations. Each therapy has associated advantages and disadvantages. However, the main drawback associated with most therapies is inadequate efficacy as a result of an insufficient local concentration. This may be due to minimal localization at the appropriate site of action when administered systemically, or as a result of clearance and destruction by inflammatory cells when administered locally. One route to address this concern is by the use of biomaterial systems as reservoirs of therapeutics to locally deliver and sustain effective concentrations for a prolonged period of time. Protein and gene delivery through scaffolds holds much promise to produce efficacious therapies (O'Rorke et al., 2010; Monaghan and Pandit, 2011; Censi et al., 2012). Natural biomaterials are capable of loading and releasing therapeutics through MMP-mediated biodegradation, with collagen in particular standing out for its usefulness (Browne et al., 2013). However, synthetic materials may allow for increased control over degradation and release kinetics of therapeutics, with the caveat that the material itself and its degradation products must cause a minimal response when implanted in vivo.

A further consideration that must be taken into account is the form the biomaterial system takes. Three typical structures that biomaterials can take are solid scaffolds, hydrogels, and particles, shown in Figure 1A. The choice of biomaterial structure is dependent on a number of factors, primarily the tissue being targeted and also the nature of the anti-inflammatory therapeutic incorporated. For example, solid scaffolds require surgery to implant, and thus are more suitable for wound healing applications
A
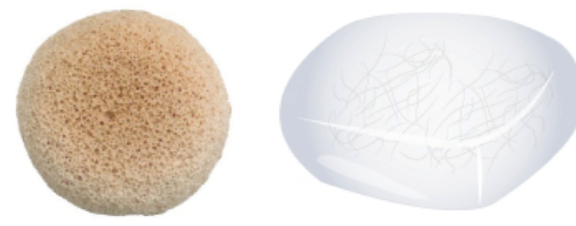

Hydrogels scaffolds
B

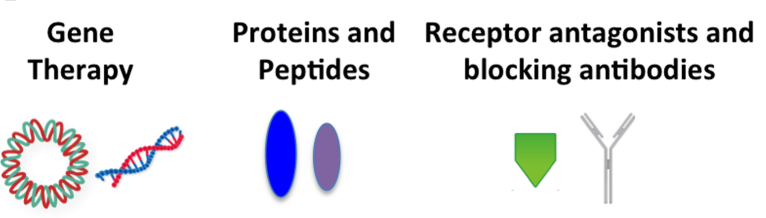

Drugs

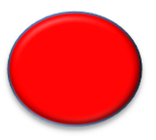

Modified and unmodified cells

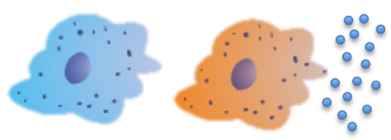

Micro- and Nanoparticles

FIGURE 1 | Biomaterials to reduce inflammation: (A) biomaterial forms used to deliver therapeutics and (B) anti-inflammatory therapeutics that have been delivered. 
in which they may be applied to an open wound. In contrast, in situ gelling hydrogels and particles can typically be delivered in a minimally invasive manner using a syringe without the need for open surgery. Thus, hydrogels and particles are suitable for delivery directly into tissues such as muscle and the myocardium. However, in terms of loading, they differ. Particles are most suited for protein, gene, and drug delivery (Sehgal and Srinivasan, 2009; Browne et al., 2012; Kraskiewicz et al., 2013). Hydrogels may not only be used for protein, gene, and drug delivery but also for cells. Hydrogels can be designed to provide a microenvironment that can be tuned to protect implanted cells, promoting cell survival, and improving function (Seliktar, 2012). Meanwhile, solid scaffolds have also been loaded with proteins, nucleic acids, and drugs, in addition to acting as matrices to enhance cell transplantation (Thevenot et al., 2010; Holladay et al., 2011; Hortensius et al., 2015). Thus, the choice of biomaterial form is dependent on the tissue into which it will be implanted, and the anti-inflammatory agent being delivered. The main biomaterial approaches to reducing inflammation will be discussed in terms of the type of biomaterial structure used.

\section{Solid Scaffolds}

The incorporation of stromal cell-derived factor-1 alpha (SDF$1 \alpha$ ) into a poly (lactic-co-glycolic acid) PLGA scaffold reduced the inflammatory response when implanted into the subcutaneous space in mice (Thevenot et al., 2010). While SDF-1 $\alpha$ is typically associated with increased angiogenesis, it can also exert anti-inflammatory effects through its mobilization and homing effect on stem cells (Ceradini et al., 2004; Ceradini and Gurtner, 2005). Thus, it was shown that incorporation of SDF- $1 \alpha$ in PLGA scaffolds reduced the inflammatory tissue response through an increase in autologous stem recruitment to the implant site. Furthermore, a reduction in pro-inflammatory cytokines was detected, with reduced expression of a number of key mediators including interleukin-1 alpha (IL-1 $\alpha$ ), interleukin-6 (IL-6), and tumor necrosis factor alpha (TNF- $\alpha$ ), while there was an increase in vascular endothelial growth factor (VEGF) expression.

Modification of the inflammatory response to a carbodiimide crosslinked collagen scaffold was achieved by codelivery of a plasmid encoding IL-10 ( $p$ IL-10). Treatment with the $p \mathrm{IL}-10$ reduced the inflammatory response to the implanted collagen scaffolds in a subcutaneous model, with a reduction seen in infiltrating macrophages (ED1 positive cells). However, a subsequent reduction in vascularization was also observed (van Putten et al., 2009). A collagen scaffold with MSCs incorporated was further functionalized with $p$ IL-10 polyplexes in an effort to reduce inflammation in an intramuscular model, and to promote the survival of the MSCs. It was observed that $p \mathrm{IL}-10$ polyplex treatment reduced inflammation and increased MSC survival (Holladay et al., 2011). When this system was implanted in a rodent model of myocardial infarction (MI), reduced inflammation was detected along with functional recovery of the heart, in terms of improved ejection fraction (Holladay et al., 2012). Furthermore, a change in macrophage phenotype was detected. Macrophages were seen to change from a classically activated, pro-inflammatory phenotype in control groups to an alternatively activated, anti-inflammatory phenotype following treatment with $\mathrm{PIL}-10$ polyplexes and MSCs.
Macrophage phenotype has been shown to be a key component of the inflammatory response to implanted biomaterials (van Putten et al., 2013; Spiller et al., 2014), and thus strategies to control the phenotype of macrophages may prove vital to modify inflammation. Incorporation of highly sulfated glycosaminoglycans (GAGs) into collagen scaffolds has enabled the control of monocyte differentiation and macrophage phenotype in vitro (Kajahn et al., 2012). A reduction of pro-inflammatory cytokine secretion and an increase in anti-inflammatory cytokines were observed when primary macrophages were cultured with a collagen scaffold containing highly sulfated GAGs, in comparison with a collagen scaffold with either no GAGs incorporated or a less sulfated GAG incorporated. However, the application of this system in pre-clinical models is crucial to determine its potential usefulness in controlling macrophage phenotype in disease states.

A silk-fibroin/HA scaffold was used to treat post-MI inflammation. In addition to providing a structural support to the damaged myocardium, it was found that treatment with the composite silkfibroin/HA reduced macrophage infiltration (CD68 positive cells) in comparison with a non-treated infarct (Chi et al., 2012). In addition, there was an increase in macrophages when bone marrow mesenchymal stem cells (BMSCs) were incorporated within the scaffold. The authors attribute this to the fact that the cells were obtained from male rats and transplanted in female rats. However, incorporation of the BMSCs improved myocardial function (wall thickness and fractional shortening), primarily through an increase in angiogenic factors and a resultant increase in vascular area. This emphasizes that reducing inflammation is an important factor, but that a multi-faceted approach is typically necessary to ensure adequate healing. Conversely, it was found in a separate study that a HA-based scaffold did not reduce inflammation unless it was coupled with MSCs (Muscari et al., 2013). This could be related to possible differences in the molecular weight of HA used. An increase in the vascular density was observed with MSC delivery, as with the previous study.

Delivery of ibuprofen from an electrospun, acid responsive poly (L-lactide) (PLLA) scaffold improved regeneration in a muscle wound model. Incorporation of sodium bicarbonate induced acid responsiveness of the PLLA scaffold, as it was observed that ibuprofen release was increased when the $\mathrm{pH}$ was changed from 7.4 to 5 , whereas this property was not observed without the incorporation of the sodium bicarbonate. It was found that the ibuprofen reduced the inflammatory response as measured by immunohistochemical staining and assessment of gene expression of IL- 6 and TNF- $\alpha$, which resulted in improved muscle regeneration (Yuan et al., 2014). In a similar study, tetrandrine, an anti-inflammatory agent, was incorporated into a PLLA scaffold. It was found that this system could reduce the production of pro-inflammatory cytokines both in vitro and in vivo (Wang et al., 2014a). A subcutaneous study revealed that the tetrandrineloaded scaffold had a reduced inflammatory response compared with the unloaded scaffold at 1,4 , and 12 weeks.

Delivery of $\mathrm{pIL}-10$ was proposed as a mechanism by which to reduce the inflammatory response to porous poly (lactide-coglycolide) (PLG) scaffolds. It was found that a macrophage cell line, RAW 264.7 cells, markedly reduced TNF- $\alpha$ and increased IL-10 expression when cultured in the presence of the PLG 
scaffolds, the IL-10 gene, and lipopolysaccharide (LPS) (Gower et al., 2014). This indicates a more anti-inflammatory nature of the macrophages following treatment with the IL-10 gene-loaded scaffold. Increased expression of IL-10 in vivo resulted in a reduction in leukocyte infiltration in the PLG scaffolds after 7 days. A decrease was also observed in the expression of interferon gamma (IFN- $\gamma$ ), but no difference was observed in the expression of IL-1 $\beta$ or TNF- $\alpha$ when compared with the control scaffolds. A follow-on study revealed that the mechanism behind this anti-inflammatory nature was a change in the phenotype of macrophages following treatment with the $p \mathrm{IL}-10$ gene. It was found that transduction of RAW 264.7 macrophages with pIL-10 resulted in a switch toward a more regulatory macrophage phenotype, as well as preventing a shift toward a more inflammatory phenotype when in a proinflammatory environment (IFN- $\gamma$ and LPS) (Boehler et al., 2014). A reduction in NF-kB activation was also observed following $p I L-$ 10 delivery, which was consistent with the reduction observed in TNF- $\alpha$ expression.

A sphingosine 1-phosphate receptor-3 agonist (FTY720) was used to modify the inflammatory response to a PLGA film. It was found that following implantation of a PLGA film, FTY720 delivery increased the arteriole and length density (Awojoodu et al., 2013). This was found to be as a result of an increase in the infiltration of anti-inflammatory monocytes to the site of implantation. In vitro studies revealed that FTY720 treatment changed the profile of inflammatory and regenerative cytokine secretion in both pro- and anti-inflammatory macrophages as well as human umbilical vein endothelial cells (HUVECs).

The examples discussed above (summarized in Table 1) provide an overview of the range of therapeutics that have been incorporated into solid biomaterial scaffolds. Therapeutics can be added to the scaffold immediately prior to implantation, or conjugated via linker systems. The incorporated therapeutics can help to overcome inflammation associated with the FBR, as well as any pre-existing pathological inflammation. The choice of therapeutic is dependent on the biomaterial itself, as well as the site into which it will be implanted. Thus, it is imperative to consider each pathology individually, rather than a 'one size fits all' approach. Furthermore, depending on the context of the injury, as well as the selected material, solid scaffold may be capable of providing mechanical support, i.e., in the case of bone scaffolds, or functions as a barrier in the case of dermal wounds.

\section{Hydrogels}

One of the main reasons why anti-inflammatory therapy has become important in relation to biomaterials is to protect implanted cells and prevent rejection by the host. This can be elucidated with the example of islet cell delivery. Ideally, implanted islet cells will not be rejected by the body, and can produce insulin efficiently to correct diabetes. However, this is not the case in actuality, as the host often rejects the implanted cells and their function is compromised. Attempts to immuno-isolate cells using biomaterials have not proven successful, and thus anti-inflammatory signals are necessary to prevent rejection by the host immune system. Encapsulation in a biomaterial alone has not proved efficacious, and thus the incorporation of anti-inflammatory agent is the next logical step. Su et al. encapsulated islet cells in a
PEG-based hydrogel, and conjugated an inhibitory peptide to the IL-1 receptor (IL-R1) (Su et al., 2010). This increased the survival of encapsulated cells in vitro following exposure to IL- $1 \beta$, IFN- $\gamma$, and TNF- $\alpha$, while islet cells were also able to continue glucosestimulated release of insulin when incubated with $\beta$-cell specific T-lymphocytes.

Hyaluronic acid hydrogels have been extensively studied as materials to deliver anti-inflammatory therapies due to their biodegradable nature, as well as their own potential antiinflammatory nature, which is dependent on the molecular weight chosen (Nakamura et al., 2004). Conjugation of dexamethasone to the HA was performed to increase drug retention by reducing diffusion from the hydrogel (Ito et al., 2007). In vitro studies revealed that the released dexamethasone reduced the expression of TNF$\alpha$ and IL- 6 from LPS-treated macrophages in a dose-dependent manner. Furthermore, in vivo studies showed that dexamethasone conjugated hydrogels had a reduced inflammatory response after 2 days when implanted subcutaneously. In a similar study, an antiTNF- $\alpha$ antibody was conjugated to a HA hydrogel and applied to a burn wound (Friedrich et al., 2014). This treatment appeared to reduce the thickness of non-viable tissue, as well as IL-1 $\beta$ concentration and macrophage infiltration compared with the control.

Chitosan is a polysaccharide derived from crustaceans. It has been used for many biomedical applications (Khor and Lim, 2003; Jayakumar et al., 2010, 2007; Prabaharan, 2008). Specifically, it is commercially available as a bandage due to its clotting ability and its anti-bacterial properties (Chirkov, 2002). The addition of adipose-derived mesenchymal stem cells (ADSCs) to a chitosan hydrogel was seen to improve their survival in the infarcted myocardium (Liu et al., 2012). In vitro studies demonstrated the ROS scavenging properties of chitosan and its degradation products. MI was induced by permanent ligation of the coronary artery, followed by injection of the chitosan/ADSCs system. Treatment with the chitosan/ADSCs system resulted in a reduction in ROS, as observed by a reduction in dihydroethidium (DHE) staining. An improvement was observed at 4 weeks in ejection fraction and fractional shortening, while there was a reduction in apoptosis seen at 1 week. Additionally, there was a reduction in infarct size as well as an increase in wall thickness and vessel density in the infarct site. This study demonstrates the antiROS properties of chitosan, as it is hypothesized that chitosan enhances stem cell retention and survival in the myocardium (which was confirmed by in vivo bioluminescence imaging), partly due to its ability to scavenge ROS. This system was also utilized to treat ischemic injury in the kidney (Gao et al., 2012). A similar effect was observed, with a reduction in ROS expression, increased cell retention, and increased number of blood vessels.

A large-scale study was performed to identify a suitable antiinflammatory drug for local immunosuppression of islet cells. From a large range of anti-inflammatory drugs, curcumin was identified as being capable of reducing inflammation and ensuing fibrosis following implantation of PLGA particles (Dang et al., 2013). Subsequent encapsulation of islet cells in alginate microcapsules, along with the identified anti-inflammatory curcumin, improved survival of the islet cells in vivo, with reduced fibrosis 
TABLE 1 | Examples of anti-inflammatory therapies delivered from solid scaffolds.

\begin{tabular}{|c|c|c|c|c|c|c|}
\hline $\begin{array}{l}\text { Biomaterial } \\
\text { system }\end{array}$ & Therapeutic & Dose & In vitro characterization & In vivo model & In vivo outcome & Reference \\
\hline PLGA & SDF- $1 \alpha$ & $\begin{array}{l}50 \mu \mathrm{g} \\
\mathrm{SDF}-1 \alpha\end{array}$ & Stem cell migration assay & $\begin{array}{l}\text { Mouse } \\
\text { subcutaneous } \\
\text { implantation }\end{array}$ & $\begin{array}{l}\text { Increased vessel density } \\
\text { Enhanced MSC engraftment } \\
\text { Reduced inflammatory response } \\
(\mathrm{IL}-1 \alpha, \mathrm{IL}-6, \mathrm{TNF}-\alpha)\end{array}$ & $\begin{array}{l}\text { Thevenot } \\
\text { et al. (2010) }\end{array}$ \\
\hline Collagen & IL-10 pDNA & $\begin{array}{l}2.5 \mu \mathrm{g} \| \mathrm{L}-10 \\
\text { pDNA }\end{array}$ & $\mathrm{n} / \mathrm{a}$ & $\begin{array}{l}\text { Rat subcutaneous } \\
\text { model }\end{array}$ & $\begin{array}{l}\text { Reduced cell infiltration } \\
\text { Reduced EDI+ cells } \\
\text { Reduced collagenase activity }\end{array}$ & $\begin{array}{l}\text { van Putten } \\
\text { et al. (2009) }\end{array}$ \\
\hline Collagen & $\begin{array}{l}\text { IL-10 pDNA } \\
\text { polyplexes } \\
\text { and MSCs }\end{array}$ & $\begin{array}{l}2 \mu \mathrm{g} I \mathrm{~L}-10 \\
\text { pDNA }\end{array}$ & $\begin{array}{l}\text { IL-10 secretion } \\
\text { Metabolic activity }\end{array}$ & $\begin{array}{l}\text { Rat intramuscular } \\
\text { implantation model }\end{array}$ & $\begin{array}{l}\text { Increased stem cell survival } \\
\text { Increased ratio of regulatory to } \\
\text { inflammatory macrophages }\end{array}$ & $\begin{array}{l}\text { Holladay } \\
\text { et al. (2011) }\end{array}$ \\
\hline Collagen & $\begin{array}{l}\text { IL-10 pDNA } \\
\text { polyplexes } \\
\text { and MSCs }\end{array}$ & $\begin{array}{l}2 \mu \mathrm{g} \mathrm{IL}-10 \\
\text { pDNA }\end{array}$ & $\mathrm{n} / \mathrm{a}$ & $\begin{array}{l}\text { Rat myocardial } \\
\text { infarction model }\end{array}$ & $\begin{array}{l}\text { Improved cardiac function and stem } \\
\text { cell survival } \\
\text { Increased ratio of regulatory to } \\
\text { inflammatory macrophages } \\
\text { Reduction in apoptosis }\end{array}$ & $\begin{array}{l}\text { Holladay } \\
\text { et al. (2012) }\end{array}$ \\
\hline $\begin{array}{l}\text { Silk-fibroin/ } \\
\text { hyaluronic acid }\end{array}$ & $\mathrm{n} / \mathrm{a}$ & $\mathrm{n} / \mathrm{a}$ & $\mathrm{n} / \mathrm{a}$ & $\begin{array}{l}\text { Rat myocardial } \\
\text { infarction model }\end{array}$ & $\begin{array}{l}\text { Reduced CD68+ cells } \\
\text { Improved wall thickness and } \\
\text { fractional shortening } \\
\text { Reduced apoptosis } \\
\text { Increased vascular density, and } \\
\text { VEGF, bFGF, and HGF expression }\end{array}$ & $\begin{array}{l}\text { Chi et al. } \\
(2012)\end{array}$ \\
\hline Hyaluronic acid & MSCs & $0.2-1 \times 10^{6}$ & $\begin{array}{l}\text { MSC proliferations } \\
\text { VEGF expression }\end{array}$ & $\begin{array}{l}\text { Porcine myocardial } \\
\text { infarction model }\end{array}$ & $\begin{array}{l}\text { Reduced CD3+ cells } \\
\text { Reduced inflammatory score }\end{array}$ & $\begin{array}{l}\text { Muscari et al. } \\
\text { (2013) }\end{array}$ \\
\hline Poly (L-lactide) & Ibuprofen & Not specified & $\begin{array}{l}\text { Ibuprofen release prolife in } \\
\text { neutral and acidic } \mathrm{pH} \\
\text { Fiber diameter }\end{array}$ & $\begin{array}{l}\text { Rat muscle wound } \\
\text { model }\end{array}$ & $\begin{array}{l}\text { Improved muscle regeneration } \\
\text { Reduced IL- } 6 \text { and TNF- } \alpha \text { and IL- } 6 \\
\text { (protein and gene expression) } \\
\text { Increased VEGF and TGF- } \beta \text { (protein } \\
\text { and gene expression) }\end{array}$ & $\begin{array}{l}\text { Yuan et al. } \\
\text { (2014) }\end{array}$ \\
\hline $\begin{array}{l}\text { Poly (L-lactic } \\
\text { acid) }\end{array}$ & Tetrandrine & 5-20 mg/g & $\begin{array}{l}\text { Tetrandrine release } \\
\text { Cell viability } \\
\text { RAW } 264.7 \text { production of } \\
\text { NO, TNF- } \alpha \text {, and IL- } 6 \text { on } \\
\text { scaffold } \\
\text { Reduction in gene } \\
\text { expression of iNOS, } \\
\text { TNF- } \alpha, \text { IL- } 6 \text {, and Cox-II }\end{array}$ & $\begin{array}{l}\text { Rat wound healing } \\
\text { model }\end{array}$ & $\begin{array}{l}\text { Reduction in inflammation in } \\
20 \mathrm{mg} / \mathrm{g} \text { tetrandrine group observed } \\
\text { on H\&E stained sections }\end{array}$ & $\begin{array}{l}\text { Wang et al. } \\
(2014 a, b)\end{array}$ \\
\hline $\begin{array}{l}\text { Poly (lactide-co- } \\
\text { Glycolide) }\end{array}$ & $\begin{array}{l}\text { IL-10 viral } \\
\text { vector }\end{array}$ & $\begin{array}{l}2 \times 10^{7} \text { viral } \\
\text { particles }\end{array}$ & $\begin{array}{l}\text { Reduced RAW } 264.7 \\
\text { production of TNF- } \alpha \text { and } \\
\text { increased IL-10 following } \\
\text { LPS treatment }\end{array}$ & $\begin{array}{l}\text { Implantation into } \\
\text { intraperitoneal } \\
\text { mouse fat pad }\end{array}$ & $\begin{array}{l}\text { Reduced leukocyte infiltration } \\
\text { Increased IL-10 expression and } \\
\text { reduced IFN- } \gamma \text { expression }\end{array}$ & $\begin{array}{l}\text { Gower et al. } \\
(2014)\end{array}$ \\
\hline $\begin{array}{l}\text { Poly (lactic-co- } \\
\text { Glycolic acid) } \\
\text { film }\end{array}$ & FTY720 & $\begin{array}{l}\text { 1:200 drug- } \\
\text { to-polymer } \\
\text { weight }\end{array}$ & $\begin{array}{l}\text { Change in cytokine } \\
\text { secretion of RAW } 264.7 \\
\text { and HUVEC }\end{array}$ & $\begin{array}{l}\text { Dorsal skinfold and } \\
\text { muscle ischemia } \\
\text { models }\end{array}$ & $\begin{array}{l}\text { Increase in presence of } \\
\text { anti-inflammatory macrophages } \\
\text { Increased arteriole and length } \\
\text { density }\end{array}$ & $\begin{array}{l}\text { Awojoodu } \\
\text { et al. (2013) }\end{array}$ \\
\hline
\end{tabular}

of the capsules and improved glycemic control in a chemically induced mouse type 1 diabetes model.

The anti-inflammatory drug resveratrol reduced inflammation in a cartilage defect model when delivered via a collagen hydrogel (Wang et al., 2014b). Resveratrol was grafted to poly (acrylic acid) and incorporated within a type I collagen hydrogel. Following delivery within a rabbit osteochondral defect model, treatment with resveratrol reduced inflammatory gene expression (IL-1 $\beta$, MMP-13 and COX-2), with a resultant increase in bone and cartilage related genes (SOX-9, aggrecan, and collagen I and III). Gross and histological examination revealed the formation of cartilagelike neotissue, which compared favorably with no treatment and a collagen hydrogel without resveratrol.

A gelatin hydrogel was loaded with an anti-inflammatory peptide (triptolide) and BMP-2 to increase bone regeneration (Ratanavaraporn et al., 2012). It was found that incorporation of the anti-inflammatory peptide reduced the infiltration of inflammatory cells, except at the highest dose $(10 \mathrm{mg})$, which indicates the importance of dose-response studies. Expression of IL-6, TNF$\alpha$, and NF-kB mRNA was also reduced. Reduced infiltration 
of inflammatory cells resulted in an increase in bone formation and bone mineral density, when accompanied by BMP-2 delivery. This study highlights the possibility of combining antiinflammatory therapies with complementary therapeutics for the treatment of complex pathologies. In this case, addition of an osteoinductive protein, BMP-2, was essential for the formation of bone, while reduced inflammation serves to enhance this function.

A peptide nanofiber gel was loaded with dexamethasone to modify the inflammatory response (Webber et al., 2012). In vitro studies revealed that delivery of the dexamethasone from the peptide nanofiber gel reduced NF-kB activation in LPS treated THP-1 monocytes. An in vivo subcutaneous study revealed that in comparison with an unloaded peptide nanofiber gel, dexamethasone loaded gels reduced the presence of ROS and inflammatory cells after 3 and 21 days.

A PEG-maleimide hydrogel was developed with on-demand protease sensitive release of IL-1RA, the naturally occurring antagonist to the IL-1R. This system was used as a coating to reduce inflammation associated with implantation of neural electrodes (Gutowski et al., 2015). Immunofluorescent staining of inflammatory cell infiltration showed no difference between samples, while RT-PCR analysis showed minimal differences, with increases in IL-6, MMP-13, and ciliary neurotrophic factor (CNTF) the only changes detected. However, the gene expression analysis does allow for the specific-targeting of genes to reduce the inflammatory response in future studies.

Hydrogels have been utilized for the delivery of a range of anti-inflammatory therapeutics (see Table 2). Hydrogels have proven particularly attractive as a matrix to assist cell transplantation. They provide an ideal substrate for cell encapsulation and protection from the host response. By engineering a suitable matrix to encourage cell adhesion and proliferation, along with the incorporation of an anti-inflammatory agent to be released in the microenvironment, the survival of implanted cells can be promoted.

\section{Micro and Nanoparticles}

Nanoparticles have been widely used to deliver anti-inflammatory therapies. Whitmire et al. fabricated a new block copolymer that assembles into sub-micron particles and contains a moiety for tethering proteins (Whitmire et al., 2012). To this moiety, IL1RA was conjugated. These particles were injected into the intraarticular joint space, where it was shown that they significantly enhanced the retention time of IL-1RA. However, to further increase retention time, the authors hypothesized that increased particle size could prove beneficial. To achieve this, a new selfassembling polymer composed of a polyhydroxyethylmethacrylate (pHEMA) backbone with a functionalized hydrophobic side chain of pyridine was fabricated, which allowed for variation in particle sizes (Singh et al., 2014). Particles of size 500 and $900 \mathrm{~nm}$ were fabricated and a fibronectin targeting ligand attached. Retention of BSA-loaded particles in the intra-articular space in the rat stifle joint was assessed using fluorescence imaging. It was found that the $900 \mathrm{~nm}$ particles were retained in the joint to a greater extent that either the soluble protein or the $500 \mathrm{~nm}$ particles.
This emphasizes the importance of the design of appropriate and efficient systems to deliver therapeutics.

Polymer particles fabricated from poly (cyclohexane-1,4diylacetone dimethylene ketal) (PCADK) were loaded with a p38 inhibitor to modulate the post-infarction inflammatory response in the myocardium (Sy et al., 2008). In an intramuscular model, the particles themselves were found to be non-inflammatory; while in an MI model, the particles significantly reduced superoxide and TNF- $\alpha$ production. This resulted in a reduction in fibrotic area as well as improved cardiac function. A similar study utilized the same particles to deliver superoxide dismutase (SOD) to the infarcted heart, which reduced superoxide expression and apoptosis (Seshadri et al., 2010). A subsequent improvement in cardiac function was also observed.

Encapsulating dexamethasone within PLGA particles reduced the in vivo inflammatory response to PLGA particles (Dang et al., 2011). It was found that encapsulation of dexamethasone within PLGA particles reduced both coverage of the PLGA particles with immune cells as well as cathepsin activity. Further investigation of the infiltration of inflammatory cells by examining histological sections revealed a reduction in the dexamethasone-loaded group compared with the unloaded control. Methylprednisolone (MP) was loaded within PLGA particles in an attempt to modify inflammation following injury of the spinal cord. The PLGA particles were suspended within an agarose gel to keep them in the local microenvironment of the injury (Chvatal et al., 2008). It was found that treatment with MP-loaded PLGA particles reduced the number of activated maicroglia, as well as the expression of the pro-inflammatory calpain and iNOS. This resulted in a reduction in lesion volume, indicating the potential of anti-inflammatory therapies in the spinal cord.

Delivery of siRNA targeting mitogen-activated protein kinase kinase kinase kinase 4 (MAP4K4) via $\beta 1,3$-D-glucan particles suppressed systemic inflammation (Aouadi et al., 2009). Delivery of the siRNA orally resulted in a reduction in MAP4K4 gene expression in the lungs, liver, and spleen. In addition, when compared to a scrambled siRNA, MAP4K4 reduced the presence of LPS-induced TNF- $\alpha$ in both the serum and peritoneal fluid. The administration of MAP4K4 siRNA reduced LPS-induced lethality by inhibiting the expression of TNF- $\alpha$ and IL-1 $\beta$. In a similar study using the same glucan particles, siRNA targeting TNF- $\alpha$ and osteopontin (OPN) was delivered systemically and localized to the macrophages present in the adipose tissue (Aouadi et al., 2013). It was found that silencing either TNF- $\alpha$ or OPN in the adipose tissue improved the glucose tolerance in ob/ob mice. Similarly, galactosylated trimethyl chitosanecysteine (GTC) nanoparticles were conjugated with MAP4K4 siRNA and delivered orally to treat ulcerative colitis (Zhang et al., 2013). It was found that this treatment reduced MAP4K4 and TNF- $\alpha$ mRNA, as well as TNF- $\alpha$ protein expression and MPO activity in the colon. Galactosylated particles showed increased efficacy compared with nongalactosylated nanoparticles, indicating the usefulness of targeting activated macrophages.

Utilization of PLGA particles to deliver PEI-conjugated Fc $\gamma$ RIII-targeting siRNA to reduce inflammation proved efficacious in a rat model of temporomandibular joint (TMJ) inflammation (Mountziaris et al., 2012). Meal pattern analysis revealed 
TABLE 2 | Examples of anti-inflammatory therapies delivered from hydrogels.

\begin{tabular}{|c|c|c|c|c|c|c|}
\hline $\begin{array}{l}\text { Biomaterial } \\
\text { system }\end{array}$ & Therapeutic & Dose & In vitro characterization & In vivo model & In vivo outcome & Reference \\
\hline $\begin{array}{l}\text { PEG hydrogel } \\
(10,000 \mathrm{Mw})\end{array}$ & $\begin{array}{l}\text { IL-1R inhibitory } \\
\text { peptide (IL-1RIP) }\end{array}$ & $\begin{array}{l}1 \% \\
\mathrm{IL}-1 \mathrm{RIP}\end{array}$ & $\begin{array}{l}\text { Cell viability and insulin secretion } \\
\text { from MIN6 cells }\end{array}$ & $\mathrm{n} / \mathrm{a}$ & $\mathrm{n} / \mathrm{a}$ & Su et al. (2010) \\
\hline Hyaluronic acid & Dexamethasone & $\begin{array}{l}2.2-4.4 \times \\
10^{-5} \mathrm{M}\end{array}$ & $\begin{array}{l}\text { Cell viability } \\
\text { Hydrogel swelling ratio } \\
\text { Dexamethasone release profile } \\
\text { Reduced IL- } 6 \text { and TNF- } \alpha \\
\text { production by RAW } 264.7\end{array}$ & $\begin{array}{l}\text { Subcutaneous } \\
\text { implantation } \\
\text { model }\end{array}$ & $\begin{array}{l}\text { Reduced infiltration of } \\
\text { macrophages and neutrophils } \\
\text { observed on H\&E stained } \\
\text { sections }\end{array}$ & Ito et al. (2007) \\
\hline Hyaluronic acid & $\begin{array}{l}\text { Anti TNF- } \alpha \\
\text { antibody }\end{array}$ & $400 \mu \mathrm{g} / \mathrm{ml}$ & Binding affinity & Rat burn models & $\begin{array}{l}\text { Reduced inflammatory cell } \\
\text { infiltration observed on H\&E } \\
\text { stained sections } \\
\text { Reduced non-viable tissue } \\
\text { Reduced IL-1 } \beta \text { protein } \\
\text { expression }\end{array}$ & $\begin{array}{l}\text { Friedrich et al. } \\
\text { (2014) }\end{array}$ \\
\hline $\begin{array}{l}\text { Chitosan } \\
\text { hydrogel }\end{array}$ & ADSCs & $\begin{array}{l}4 \times 10^{6} \\
\text { ADSCs }\end{array}$ & $\begin{array}{l}\text { Cell adhesion and expression of } \\
\text { adhesion genes in response to } \\
\text { ROS }\end{array}$ & $\begin{array}{l}\text { Rat myocardial } \\
\text { infarction model }\end{array}$ & $\begin{array}{l}\text { Increased ICAM-1, VCAM-1, } \\
\text { and SDF-1 expression and } \\
\text { ADSC retention } \\
\text { Reduction in ROS, apoptosis, } \\
\text { and infarct size } \\
\text { Increased wall thickness and } \\
\text { blood vessel density, improved } \\
\text { cardiac function }\end{array}$ & Liu et al. (2012) \\
\hline $\begin{array}{l}\text { Chitosan } \\
\text { hydrogel }\end{array}$ & ADSCs & $\begin{array}{l}2 \times 10^{6} \\
\text { ADSCs }\end{array}$ & $\mathrm{n} / \mathrm{a}$ & $\begin{array}{l}\text { Rat acute renal } \\
\text { ischemia- } \\
\text { reperfusion } \\
\text { model }\end{array}$ & $\begin{array}{l}\text { Reduction in apoptosis and } \\
\text { ROS expression } \\
\text { Increased stem cell retention } \\
\text { and renal cell proliferation } \\
\text { Reduction in serum levels of } \\
\text { creatinine and blood urea } \\
\text { nitrogen }\end{array}$ & $\begin{array}{l}\text { Gao et al. } \\
(2012)\end{array}$ \\
\hline $\begin{array}{l}\text { Alginate } \\
\text { microcapsules } \\
\text { containing islet } \\
\text { cells }\end{array}$ & Curcumin & $1 \mathrm{mg} / \mathrm{ml}$ & $\mathrm{n} / \mathrm{a}$ & $\begin{array}{l}\text { STZ-induced } \\
\text { diabetic mouse } \\
\text { model }\end{array}$ & $\begin{array}{l}\text { Improved blood glucose level } \\
\text { Reduced gene expression of } \\
\text { CD68, CD19, CD74, CD8, } \\
\text { TNF- } \alpha \text {, TGF- } \beta \text {, and } \alpha \text { SMA }\end{array}$ & $\begin{array}{l}\text { Dang et al. } \\
\text { (2013) }\end{array}$ \\
\hline $\begin{array}{l}\text { Collagen } \\
\text { hydrogel }\end{array}$ & Resveratrol & $0.5 \%$ & $\begin{array}{l}\text { Compressive strength free } \\
\text { radical scavenging } \\
\text { Collagen degradation } \\
\text { Cell viability }\end{array}$ & $\begin{array}{l}\text { Rabbit } \\
\text { osteochondral } \\
\text { defect }\end{array}$ & $\begin{array}{l}\text { Reduction in IL-1 } \beta \text {, MMP-13, } \\
\text { and Cox-II mRNA } \\
\text { Increased SOX-9, aggrecan, } \\
\text { collagen I and III mRNA } \\
\text { Improved neotissue formation } \\
\text { and integration } \\
\text { Increased collagen II deposition }\end{array}$ & $\begin{array}{l}\text { Wang et al. } \\
(2014 a, b)\end{array}$ \\
\hline Gelatin & $\begin{array}{l}\text { Triptolide [and } \\
\text { BMP-2] }\end{array}$ & $\begin{array}{l}2.5,5, \text { or } \\
10 \mathrm{mg}\end{array}$ & $\begin{array}{l}\text { Release profile } \\
\text { Relationship between } \\
\text { degradation and release profile } \\
\text { Reduction in IL-6 and IL-10 } \\
\text { protein expression in J774.1 } \\
\text { macrophage-like cells } \\
\text { Proliferation and ALP activity in } \\
\text { MC3T3-E1 cells }\end{array}$ & $\begin{array}{l}\text { Rat critical-sized } \\
\text { bone defect }\end{array}$ & $\begin{array}{l}\text { Reduced lymphocytes, } \\
\text { netrophils, and mast cells } \\
\text { Reduced mRNA expression of } \\
\text { IL-6, IL-10, TNF- } \alpha, N F-k B \text {, and } \\
\text { MMP-14 } \\
\text { Increased bone mineral density }\end{array}$ & $\begin{array}{l}\text { Ratanavaraporn } \\
\text { et al. (2012) }\end{array}$ \\
\hline $\begin{array}{l}\text { Peptide } \\
\text { amphiphile }\end{array}$ & Dexamethasone & $\begin{array}{l}\text { Not } \\
\text { specified }\end{array}$ & $\begin{array}{l}\text { Dexamethasone release } \\
\text { Reduced NF-kB activity in THP-1 } \\
\text { cells following LPS activation } \\
\text { Cell viability following treatment } \\
\text { with Dex-PA }\end{array}$ & $\begin{array}{l}\text { Mouse } \\
\text { subcutaneous } \\
\text { model }\end{array}$ & $\begin{array}{l}\text { Reduced ROS formation } \\
\text { Reduced inflammatory cell } \\
\text { infiltration observed on H\&E } \\
\text { stained sections }\end{array}$ & $\begin{array}{l}\text { Webber et al. } \\
(2012)\end{array}$ \\
\hline $\begin{array}{l}\text { Poly (ethylene } \\
\text { glycol)- } \\
\text { maleimide } \\
\text { (Coating on a } \\
\text { neural electrode) }\end{array}$ & IL-1RA & $150 \mathrm{pg}$ & $\begin{array}{l}\text { Coating thickness } \\
\text { Cell adhesion } \\
\text { Reduced expression of IL-1 } \beta \text { and } \\
\text { TNF- } \alpha \text { in microglia/astrocytes } \\
\text { treated with GMCSF } \\
\text { IL-1RA release profile }\end{array}$ & $\begin{array}{l}\text { Rat neural } \\
\text { implantation } \\
\text { model }\end{array}$ & $\begin{array}{l}\text { Increased IL-6, MMP-2, and } \\
\text { CNTF }\end{array}$ & $\begin{array}{l}\text { Gutowski et al. } \\
\text { (2015) }\end{array}$ \\
\hline
\end{tabular}


an improvement following Fc $\gamma$ RIII siRNA treatment, while a reduction was observed in the levels of two key pro-inflammatory cytokines, IL-1 $\beta$ and IL-6. Similarly, PLGA particles were used to delivery anti-TNF- $\alpha$ siRNA to treat inflammation associated with rheumatoid arthritis (RA) (Présumey et al., 2012). In vitro studies revealed that delivery of anti-TNF- $\alpha$ siRNA via PLGA particles could reduce LPS-induced TNF- $\alpha$ production in mouse monocytic J774 cells. Translation to an in vivo model of RA resulted in a reduction in TNF- $\alpha$ production and inflammation in the joint. Loading of PLGA particles with COX-2 siRNA and dexamethasone has also been proposed as a means by which to modify RA associated inflammation (Park et al., 2012). PLGA particles were loaded with dexamethasone, and then these drugloaded particles had PEI/siRNA complexes attached to them. Pretreatment of C28/I 2 cells with TNF- $\alpha$ and IL- $1 \beta$ in vitro resulted in increased expression of COX-2 and iNOS. However, treatment with PLGA particles combined with dexamethasone and COX2 siRNA reduced this induced expression. Interestingly, it was observed that dexamethasone had a minimal effect on inflammatory gene expression unless it was delivered via PLGA particles. This emphasizes the importance of the mode of delivery of an anti-inflammatory therapy, and suggests biomaterial systems as reservoirs of such therapeutics.

An annexin-A1 mimetic-peptide (Ac2-26) showed increased efficacy, when loaded within nanoparticles. Nanoparticles were fabricated from a biodegradable PLGA-b-PEG polymer using a nanoprecipitation method, with a collagen IV-targeting conjugate (Kamaly et al., 2013). These targeting nanoparticles loaded with Ac2-26 showed an increased ability to reduce the number of macrophages in an in vivo murine peritonitis model compared with non-targeting particles, srambled peptide-loaded particles, and also non-loaded particles. In an in vivo model of ischemia, targeted particles again compared favorably with scrambledpeptide loaded targeting particles and also non-targeting peptide loaded particles, with a reduction observed in myeloperoxidase activity. A similar formulation, but without the collagen IVtargeting conjugate, was used to form nanoparticles and deliver an anti-inflammatory synthetic liver X receptor agonist (GW3965) (Gadde et al., 2014). In peritoneal macrophages in vitro, it was shown that treatment with GW3965 in nanoparticle form reduced expression of monocyte chemoattractant protein 1 (MCP-1) and TNF- $\alpha$. In an in vivo model of peritonitis, a reduction was observed in macrophage numbers, and MCP- 1 and TNF- $\alpha$ gene and protein expression at a similar level to dexamethasone treatment.

A lipid nanoparticle was used to deliver a therapeutic siRNA that reduced the accumulation of pro-inflammatory monocytes to inflamed tissue (Leuschner et al., 2011). An siRNA targeting the chemokine receptor CCR2 was administered systemically, and shown to reduce the infarct size in an MI model, reduce inflammatory cells in atherosclerotic lesion, improve the survival of pancreatic islet allografts, and reduce tumor volume. This emphasizes the power of siRNA as a therapeutic modality capable of controlling cell phenotype, in this case pro-inflammatory macrophages.

Urethane acrylate non-ionomer (UAN) nanoparticles were functionalized with a targeting moiety to increase localization to tumors (Park et al., 2013). By conjugating an ICAM-1 targeting ligand to nanoparticles, localization to tumors and inflamed tissue was increased. UAN nanoparticles loaded with paclitaxel reduced the tumor volume compared without a targeting ligand. This shows the potential to target inflammation with nanoparticles and a targeting moiety. This system could be adapted to load various therapeutics, and also conjugated with different ligands for targeting of specific sights.

PLGA and chitosan were used to form bilayered nanoparticles for the delivery of two anti-inflammatory drugs, spantide II (SP) and ketoprofen (KP) (Shah et al., 2012). These nanoparticles were combined with a skin-permeating nanogel, and used in two models of allergic contact dermatitis (ACD) and psoriatic plaque. Ear thickness was reduced in the ACD model, while transepidermal water loss was reduced in the psoriatic model, the two primary endpoints in both models, indicating the power of anti-inflammatory delivery via nanoparticles.

Particulate systems, whether in the micro or nano range, are versatile delivery systems capable of delivering drugs, proteins, and nucleic acids, or combinations thereof (see Table 3). However, issues with retention at the inflamed site persist, amplified by the fact that activated macrophages clear particles in a size and shape-dependent manner (Champion and Mitragotri, 2006). Thus, choice of particle size/shape is imperative, as well as other strategies to avoid uptake and clearance. These may include tethering of "self" peptides to particles (Rodriguez et al., 2013), or combination with solid or hydrogel scaffolds to increase bulk retention in the target tissue.

\section{Future Directions}

Modulation of inflammation is a key component for the success of biomaterial and tissue engineering based strategies. This is the case both in terms of modulating the FBR to ensure the survival and functionality of implanted devices and also in delivering antiinflammatory therapeutics to sites of pathological inflammation. Thus, strategies to improve the efficacy of anti-inflammatory therapies are vital.

The inflammatory response is often quantified in terms of the number of macrophages present, the phenotype of these macrophages, or both. Thus, the macrophage is and has been identified as a key component of inflammation (Wynn and Barron, 2010; Koh and DiPietro, 2011) and the FBR to biomaterials (Xia and Triffitt, 2006; Brown et al., 2012). Furthermore, where along the spectrum of macrophage activity, these macropahages are a key determinant in whether inflammation will become resolved in a satisfactory manner (Mosser and Edwards, 2009). Thus, control over macrophage can be key to modulating inflammation and resolving it. Cytokines such as IL-4, IL-10, and IL-13 (see Figure 2) have been identified as playing a role in shifting the balance from a pro-inflammatory macrophage to that of a macrophage more antiinflammatory in nature, promoting tissue repair and remodeling (Mantovani et al., 2013). A number of biomaterial systems have been developed to deliver pDNA to macrophages (Helary et al., 2012; Mahor et al., 2012). Thus, specific delivery of molecules to direct macrophages toward an anti-inflammatory phenotype rather than a pro-inflammatory phenotype holds promise as a treatment for inflammation. 
TABLE 3 | Micro and nanoparticles used to deliver anti-inflammatory therapies.

\begin{tabular}{|c|c|c|c|c|c|c|}
\hline $\begin{array}{l}\text { Biomaterial } \\
\text { system }\end{array}$ & Therapeutic & Dose & $\begin{array}{c}\text { In vitro } \\
\text { characterization }\end{array}$ & In vivo model & In vivo outcome & Reference \\
\hline $\begin{array}{l}\text { Tetraethylene glycol } \\
\text { and cyclohexyl } \\
\text { methacrylate } \\
\text { nanoparticles }\end{array}$ & IL-1RA & $5 \mu \mathrm{g} I \mathrm{~L}-1 \mathrm{RA}$ & $\begin{array}{l}\text { Nanoparticle size } \\
\text { Target specificity } \\
\text { NF- } \kappa \beta \text { activity in NIH3T3 } \\
\text { fibroblasts }\end{array}$ & $\begin{array}{l}\text { Rat } \\
\text { intra-articular } \\
\text { model }\end{array}$ & $\begin{array}{l}\text { Increased retention of IL-1RA } \\
\text { compared with saline delivery }\end{array}$ & $\begin{array}{l}\text { Whitmire } \\
\text { et al. (2012) }\end{array}$ \\
\hline $\begin{array}{l}\text { Poly (hydroxy-ethyl- } \\
\text { methacrylate) } \\
\text { [p(HEMA)] }\end{array}$ & $\begin{array}{l}\text { (BSA as a model } \\
\text { protein) }\end{array}$ & $\begin{array}{l}500 \mu \mathrm{g} \\
\text { Vivo-Tag- } \\
\text { S750-BSA }\end{array}$ & $\begin{array}{l}\text { Particle size } \\
\text { Cell viability }\end{array}$ & $\begin{array}{l}\text { Rat } \\
\text { intra-articular } \\
\text { injection }\end{array}$ & $\begin{array}{l}\text { Increased retention compared with } \\
\text { soluble protein }\end{array}$ & $\begin{array}{l}\text { Singh et al. } \\
(2014)\end{array}$ \\
\hline $\begin{array}{l}\text { Poly (cyclohexane- } \\
\text { 1,4-diylacetone } \\
\text { dimethylene ketal) } \\
\text { (PCADK) }\end{array}$ & P38 inhibitor & $\begin{array}{l}50 \mu \mathrm{g} \text { P38 } \\
\text { inhibitor }\end{array}$ & $\begin{array}{l}\text { Particle size } \\
\text { Activation of RAW } 264.7 \\
\text { macrophages }\end{array}$ & $\begin{array}{l}\text { Rat myocardial } \\
\text { infarction model }\end{array}$ & $\begin{array}{l}\text { Reduced P38 activation, } \\
\text { superoxide, and TNF- } \alpha \text { production } \\
\text { Reduced fibrotic area and } \\
\text { improved cardiac function }\end{array}$ & $\begin{array}{l}\text { Sy et al. } \\
(2008)\end{array}$ \\
\hline $\begin{array}{l}\text { Poly (cyclohexane- } \\
\text { 1,4-diylacetone } \\
\text { dimethylene ketal) } \\
\text { (PCADK) }\end{array}$ & $\begin{array}{l}\text { Superoxide } \\
\text { dismutase } \\
\text { (SOD) }\end{array}$ & $80 \cup \mathrm{SOD}$ & $\begin{array}{l}\text { Particle size } \\
\text { Superoxide scavenging }\end{array}$ & $\begin{array}{l}\text { Rat myocardial } \\
\text { infarction model }\end{array}$ & $\begin{array}{l}\text { Reduced superoxide production } \\
\text { and apoptosis } \\
\text { Improved cardiac function }\end{array}$ & $\begin{array}{l}\text { Seshadri } \\
\text { et al. (2010) }\end{array}$ \\
\hline PLGA & Dexamethasone & $\begin{array}{l}1.3 \text { and } 26 \\
w t \%\end{array}$ & $\begin{array}{l}\text { Dexamthasone loading and } \\
\text { release }\end{array}$ & $\begin{array}{l}\text { Mouse } \\
\text { subcutaneous } \\
\text { injection }\end{array}$ & $\begin{array}{l}\text { Reduced cathepsin activity up to } \\
10 \text { days } \\
\text { Reduced inflammatory cell } \\
\text { infiltration up to } 30 \text { days }\end{array}$ & $\begin{array}{l}\text { Dang et al. } \\
\text { (2011) }\end{array}$ \\
\hline PLGA & Methylprednisolone & $156 \mu \mathrm{g}$ & $\begin{array}{l}\text { Methylprednisolone release } \\
\text { NO production by } \\
\text { LPS-treated microglia }\end{array}$ & $\begin{array}{l}\text { Rat spinal cord } \\
\text { contusion model }\end{array}$ & $\begin{array}{l}\text { Reduced ED1+ cells } \\
\text { Reduced Calplain and iNOS } \\
\text { Reduced lesion volume }\end{array}$ & $\begin{array}{l}\text { Chvatal et al. } \\
\text { (2008) }\end{array}$ \\
\hline$\beta 1,3-d-g l u c a n$ & MAP4K4 siRNA & $\begin{array}{l}20 \mu \mathrm{g} / \mathrm{kg} \\
\text { body weight }\end{array}$ & $\begin{array}{l}\text { MAP4K4 and TNF- } \alpha \\
\text { knockdown }\end{array}$ & $\begin{array}{l}\text { Mouse } \\
\text { LPS-induced } \\
\text { lethality }\end{array}$ & $\begin{array}{l}\text { Reduced MAP4K4 mRNA in } \\
\text { peritoneal macrophages, spleen, } \\
\text { liver, and lung } \\
\text { Reduced TNF- } \alpha \text { and IL-1 } \beta \text { mRNA } \\
\text { Reduced serum and peritoneal } \\
\text { TNF- } \alpha\end{array}$ & $\begin{array}{l}\text { Aouadi et al. } \\
\text { (2009) }\end{array}$ \\
\hline $\begin{array}{l}\text { Galactosylated } \\
\text { Trimethyl } \\
\text { Chitosanecysteine }\end{array}$ & MAP4K4 siRNA & $\begin{array}{l}250 \mu \mathrm{g} / \mathrm{kg} \\
\text { body } \\
\text { weight/day }\end{array}$ & $\begin{array}{l}\text { Charge and cell uptake } \\
\text { MAP4K4 and TNF- } \alpha \text { mRNA } \\
\text { knockdown } \\
\text { Reduced TNF- } \alpha \text { protein } \\
\text { expression }\end{array}$ & $\begin{array}{l}\text { Mouse } \\
\text { ulcerative colitis }\end{array}$ & $\begin{array}{l}\text { MAP4K4 and TNF- } \alpha \text { mRNA } \\
\text { knockdown } \\
\text { Reduced colonic TNF- } \alpha \text { protein } \\
\text { and MPO activity } \\
\text { Reduced infiltration of } \\
\text { mononucleur cells observed on } \\
\text { H\&E sections }\end{array}$ & $\begin{array}{l}\text { Zhang et al. } \\
(2013)\end{array}$ \\
\hline PLGA & $\begin{array}{l}\text { FcyRIII-targeting } \\
\text { siRNA }\end{array}$ & $\approx 16-23 \mu \mathrm{g}$ & $\begin{array}{l}\text { siRNA release } \\
\text { siRNA loading efficiency }\end{array}$ & $\begin{array}{l}\text { Rat temporo- } \\
\text { mandibular } \\
\text { inflammation }\end{array}$ & $\begin{array}{l}\text { Reduced IL-1 } 1 \beta \text { and IL- } 6 \text { protein } \\
\text { expression } \\
\text { Reduced Fc } \gamma R \text { RII expression }\end{array}$ & $\begin{array}{l}\text { Mountziaris } \\
\text { et al. (2012) }\end{array}$ \\
\hline PLGA & TNF- $\alpha$ siRNA & $0.12 \mathrm{nM}$ & $\begin{array}{l}\text { Particle size } \\
\text { siRNA release } \\
\text { Reduced TNF- } \alpha \text { mRNA and } \\
\text { protein expression }\end{array}$ & $\begin{array}{l}\text { Mouse collagen } \\
\text { induced arthritis }\end{array}$ & $\begin{array}{l}\text { Reduced synovial inflammatory } \\
\text { score } \\
\text { Reduced TNF- } \alpha \text { protein } \\
\text { expression }\end{array}$ & $\begin{array}{l}\text { Présumey } \\
\text { et al. (2012) }\end{array}$ \\
\hline PLGA & $\begin{array}{l}\text { Dexamethasone } \\
\text { and COX-2 } \\
\text { siRNA }\end{array}$ & $\mathrm{n} / \mathrm{a}$ & $\begin{array}{l}\text { Dexamethasone and siRNA } \\
\text { loading } \\
\text { Particle size, charge, cell } \\
\text { viability, uptake, and } \\
\text { transfection efficiency } \\
\text { PGE }_{2} \text { secretion } \\
\text { COX-2 and iNOS knockdown } \\
\text { in C28-I2 } \\
\text { Reduced mPGES-1, COX-2, } \\
\text { and iNOS protein expression } \\
\text { Reduced caspase-3 }\end{array}$ & $\mathrm{n} / \mathrm{a}$ & $\mathrm{n} / \mathrm{a}$ & $\begin{array}{l}\text { Park et al. } \\
(2012)\end{array}$ \\
\hline PLGA-b-PEG & $\begin{array}{l}\text { Ac2-26 } \\
\text { (annexin-A1 } \\
\text { mimetic peptide) }\end{array}$ & $100 \mathrm{ng}$ & $\begin{array}{l}\text { Particle size } \\
\text { Ac2-26 release }\end{array}$ & $\begin{array}{l}\text { Murine } \\
\text { peritonitis } \\
\text { Muscle ischemia }\end{array}$ & $\begin{array}{l}\text { Reduced number of PMNs } \\
\text { Reduced MPO activity }\end{array}$ & $\begin{array}{l}\text { Kamaly et al. } \\
\text { (2013) }\end{array}$ \\
\hline
\end{tabular}


TABLE 3 | Continued

\begin{tabular}{|c|c|c|c|c|c|c|}
\hline $\begin{array}{l}\text { Biomaterial } \\
\text { system }\end{array}$ & Therapeutic & Dose & $\begin{array}{c}\text { In vitro } \\
\text { characterization }\end{array}$ & In vivo model & In vivo outcome & Reference \\
\hline PLGA-b-PEG & $\begin{array}{l}\text { GW3965 (liver X } \\
\text { receptor } \\
\text { agonist) }\end{array}$ & $8 \mathrm{mg} / \mathrm{kg}$ & $\begin{array}{l}\text { Particle size } \\
\text { GW3965 release profile } \\
\text { Reduced TNF- } \alpha \text { and MCP-1 } \\
\text { gene and protein expression } \\
\text { in peritoneal macrophages }\end{array}$ & $\begin{array}{l}\text { Mouse } \\
\text { zymosan- } \\
\text { induced } \\
\text { Peritonitis }\end{array}$ & $\begin{array}{l}\text { Reduced PMN infiltration } \\
\text { Reduced TNF- } \alpha \text { and MCP-1 gene } \\
\text { and protein expression in } \\
\text { peritoneal exudates }\end{array}$ & $\begin{array}{l}\text { Gadde et al. } \\
(2014)\end{array}$ \\
\hline $\begin{array}{l}\text { C12-200 lipid, dis- } \\
\text { teroylphosphatidyl } \\
\text { choline, cholesterol, } \\
\text { and PEG-DMG }\end{array}$ & CCR2 SiRNA & $1 \mathrm{mg} / \mathrm{kg}$ & $\mathrm{n} / \mathrm{a}$ & $\begin{array}{l}\text { Mouse } \\
\text { ischemia/ } \\
\text { reperfusion } \\
\text { Mouse } \\
\text { permanent } \\
\text { ligation } \\
\text { Mouse } \\
\text { streptozotocin- } \\
\text { induced } \\
\text { diabetes } \\
\text { Mouse islet } \\
\text { transplantation } \\
\text { Mouse tumor } \\
\text { xenograft model }\end{array}$ & $\begin{array}{l}\text { Reduced CCR2 expression } \\
\text { Reduced myocardial area-at-risk } \\
\text { Reduced Ly-6Chigh macrophages, } \\
\text { CD11b+ cells, and lesion volume } \\
\text { in atheresclerotic plaque } \\
\text { Increased survival of pancreatic } \\
\text { islet allografts } \\
\text { Reduced tumor volume, tumor } \\
\text { associated macrophages, and } \\
\text { CD11b+ cells }\end{array}$ & $\begin{array}{l}\text { Leuschner } \\
\text { et al. (2011) }\end{array}$ \\
\hline $\begin{array}{l}\text { Urethane acrylate } \\
\text { non-ionomer (UAN) }\end{array}$ & Paclitaxel & $\begin{array}{l}200 \mu g \text { UAN- } \\
\text { Paclitaxel } \\
\text { nanoparti- } \\
\text { cles }\end{array}$ & Viability and dose response & $\begin{array}{l}\text { Mouse tumor } \\
\text { cytotoxicity } \\
\text { assay }\end{array}$ & Reduced tumor volume & $\begin{array}{l}\text { Park et al. } \\
\text { (2013) }\end{array}$ \\
\hline PLGA and chitosan & $\begin{array}{l}\text { Spantide II and } \\
\text { ketoprofen }\end{array}$ & Not specified & $\begin{array}{l}\text { Particle loading efficiency } \\
\text { Spantide II and ketoprofen } \\
\text { release profile }\end{array}$ & $\begin{array}{l}\text { Mouse allergic } \\
\text { contact } \\
\text { dermatitis }\end{array}$ & $\begin{array}{l}\text { Increased drug retention } \\
\text { Reduced ear } \\
\text { Reduced IL-17 and IL-23 } \\
\text { expression } \\
\text { Reduced trans-epidermal water } \\
\text { loss }\end{array}$ & $\begin{array}{l}\text { Shah et al. } \\
\text { (2012) }\end{array}$ \\
\hline
\end{tabular}

\section{Pro-inflammatory}

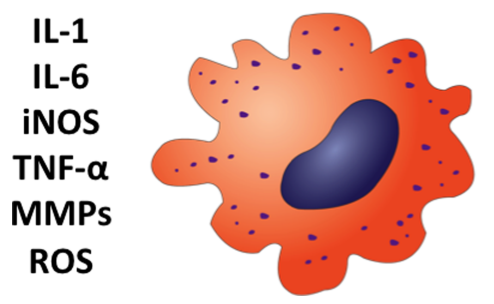

FIGURE 2 | Macrophage phenotype: inflammation may be controlled by modulation of the phenotype from a pro-inflammatory nature to anti-inflammatory and wound healing. Cytokines including $\mathrm{IL}-4, \mathrm{IL}-10$, and
IL-4, IL-10 \& IL-13

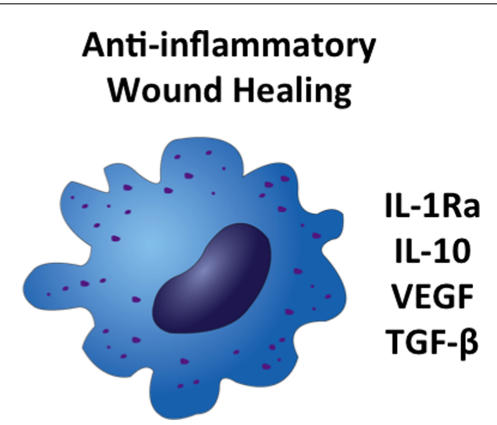

IL-13 have been implicated in the transition of macrophages from a pro-inflammatory phenotype to a more regulatory, anti-inflammatory and wound healing phenotype in vivo.
A number of natural biomaterials have intrinsic antiinflammatory properties, including $\mathrm{HA}$ and chitosan. Thus, they are suitable as carriers for anti-inflammatory therapeutics. However, synthetic materials are also capable of acting in an anti-inflammatory way. Dead and dying cells release their contents, including nucleic acids, both RNA and DNA. These nucleic acids act as DAMPs and activate toll like receptors (TLRs), stimulating an inflammatory response. It was found that binding of nucleic acids produced by injury by cationic polymers reduces associated inflammation, both in vitro and in vivo (Lee et al.,
2011). This ability to act as a molecular scavenger for nucleic acids could be adapted for other molecules, with a biomaterial acting as a "sponge" to scavenge and absorb pro-inflammatory cytokines in an inflamed environment. However, a more specific approach, possibly involving conjugation of pro-inflammatory targeting antibodies, would be necessary to avoid the uptake of all cytokines and growth factors. In a similar way, materials may be protected from an inflammatory response by the conjugation of immunomodulatory "self" proteins. Attachment of CD200 protein to a biomaterial surface reduced the production of TNF- $\alpha$ 
and IL-6 in vitro in response to LPS and IFN- $\gamma$ stimulation, by activating pathways that inhibit inflammation (Kim et al., 2014). This anti-inflammatory nature was confirmed in vivo using bioluminescence imaging to detect ROS activity. In comparison with unmodified materials, the CD200 modified material displayed a drastically reduced tissue response. Strategies such as this may reduce inflammation in the context of implantable devices, but may also be used as a means by which to reduce inflammation locally in a pathological condition.

Nanoparticles can be used to deliver multiple therapeutics. Codelivery of IL-10 siRNA and a pDNA vaccine using PLGAPEI nanoparticles were used to modify the Th1 to Th2 balance during immunotherapy (Singh et al., 2008). Similarly, lipid-like nanoparticles were used to simultaneously deliver both pDNA and siRNA (Dong et al., 2014). In vivo studies showed the potential to upregulate luciferase activity and reduce Tie-2 expression using a luciferase pDNA, and a Tie-2 targeting siRNA. Selection of different nucleic acids creates an opportunity to upregulate an antiinflammatory mediator while knocking down a pro-inflammatory mediator concurrently. This may prove key as inflammation is a complex phenomenon that requires multiple points of control.

Responsive systems are a well-utilized facet of biomaterial design. In order to design biodegradable systems, crosslinkers with MMP-cleavable sequences are incorporated into typically non-degradable sequences. In this way, MMP sensitivity is built into the system. Therapeutics may also be conjugated to biomaterials using sensitive linker systems. That is, the therapeutic will be released in response to a pre-determined stimulus. For example, previously therapeutics have been conjugated to a fibrin scaffold such that they would only be released by MMP activity, resulting in improved efficacy (Zisch et al., 2003; Ehrbar et al., 2004). ROS sensitivity has been identified as a key mediator for the release of therapeutics (Yoshitomi and Nagasaki, 2014). Nanoparticles composed of $\beta$-cycoldextrin were engineered with ROS sensitivity, and tested in vitro and in vivo. ROS responsive-release of docetaxal from nanoparticles in vivo was assessed as a means by which to reduce tumor volume (Zhang et al., 2015).

As stated, inflammation is a key determinant in the FBR and how it progresses. In addition, in plays a key role in the progression of a number of pathological conditions in which it is dysregulated. However, in most cases, dysregulation of and excessive inflammation is not the only process involved. For instance, in

\section{References}

Alexander, J. C., Browne, S., Pandit, A., and Rochev, Y. (2013). Biomaterial constructs for delivery of multiple therapeutic genes: a spatiotemporal evaluation of efficacy using molecular beacons. PLoS ONE 8:e65749. doi:10.1371/journal. pone.0065749

Anderson, J. M., Rodriguez, A., and Chang, D. T. (2008). Foreign body reaction to biomaterials. Semin. Immunol. 20, 86-100. doi:10.1016/j.smim.2007.11.004

Aouadi, M., Tencerova, M., Vangala, P., Yawe, J. C., Nicoloro, S. M., Amano, S. U., et al. (2013). Gene silencing in adipose tissue macrophages regulates wholebody metabolism in obese mice. Proc. Natl. Acad. Sci. U.S.A. 110, 8278-8283. doi:10.1073/pnas. 1300492110

Aouadi, M., Tesz, G. J., Nicoloro, S. M., Wang, M., Chouinard, M., Soto, E., et al. (2009). Orally delivered siRNA targeting macrophage Map4k4 suppresses systemic inflammation. Nature 458, 1180-1184. doi:10.1038/nature07774 the case of diabetic wound healing, inflammation is excessive, but there are also issues with insufficient angiogenesis as well as ECM turnover. Thus, approaches that aim to reduce inflammation and also modulate other processes are needed. Biomaterial systems can be designed to load and release multiple, complementary therapeutics (Browne and Pandit, 2014). A multi-modal system composed of fibrin microspheres in a fibrin hydrogel was used to modify inflammation and angiogenesis, through the delivery of two pDNAs encoding Rab18 and endothelial nitric oxide synthase (eNOS) (Kulkarni et al., 2014). This improved healing in a diabetic rabbit wound model. A similar system composed of collagen spheres-in-hydrogel was used to deliver IL-10 and eNOS pDNA in a staggered manner in vitro (Alexander et al., 2013), while in vivo assessment of dual delivery of anti-inflammatory and pro-angiogenic peptides showed a combinatorial effect (Zachman et al., 2012).

\section{Outlook}

Control over inflammation is vital for the success of biomaterial and tissue engineered therapies. Modification of inflammation is key to reducing the impact of the FBR. In addition, biomaterials also offer the opportunity to control inflammation in pathological conditions, through increased localization and retention of therapies in the inflamed microenvironment. The form of biomaterial used (solid scaffold, hydrogel, or micro/nanoparticle) is dependent on the target site, with considerations such as ease of access and retention paramount. In addition, the choice of antiinflammatory therapeutics is typically dependent on the cause of inflammation.

Future therapeutics will focus on control of macrophage phenotype, the use of anti-inflammatory materials, complementary combinations of anti-inflammatory therapeutics, and biomaterial systems that release anti-inflammatory therapeutics in response to inflammatory stimuli, such as ROS and MMPs.

\section{Acknowledgments}

The authors would like to acknowledge financial support from Science Foundation Ireland (Grant nos. 07/SRC/B1163, 13/RC/2073). The authors would like to thank Mr. Maciej Doczyk for assistance with graphics and Mr. Anthony Sloan for editorial assistance.

Awojoodu, A. O., Ogle, M. E., Sefcik, L. S., Bowers, D. T., Martin, K., Brayman, K. L., et al. (2013). Sphingosine 1-phosphate receptor 3 regulates recruitment of anti-inflammatory monocytes to microvessels during implant arteriogenesis. Proc. Natl. Acad. Sci. U.S.A. 110, 13785-13790. doi:10.1073/pnas.1221309110

Boehler, R. M., Kuo, R., Shin, S., Goodman, A. G., Pilecki, M. A., Leonard, J. N., et al. (2014). Lentivirus delivery of IL-10 to promote and sustain macrophage polarization towards an anti-inflammatory phenotype. Biotechnol. Bioeng. 111, 1210-1221. doi:10.1002/bit.25175

Brown, B. N., Londono, R., Tottey, S., Zhang, L., Kukla, K. A., Wolf, M. T., et al. (2012). Macrophage phenotype as a predictor of constructive remodeling following the implantation of biologically derived surgical mesh materials. Acta Biomater. 8, 978-987. doi:10.1016/j.actbio.2011.11.031

Browne, S., Fontana, G., Rodriguez, B. J., and Pandit, A. (2012). A protective extracellular matrix-based gene delivery reservoir fabricated by electrostatic charge manipulation. Mol. Pharm. 9, 3099-3106. doi:10.1021/mp300231d 
Browne, S., and Pandit, A. (2014). Multi-modal delivery of therapeutics using biomaterial scaffolds. J. Mater. Chem. B Mater. Biol. Med. 2, 6692-6707. doi:10. 1039/C4TB00863D

Browne, S., Zeugolis, D. I., and Pandit, A. (2013). Collagen: finding a solution for the source. Tissue Eng. Part A 19, 1491-1494. doi:10.1089/ten.TEA.2012.0721

Censi, R., Di Martino, P., Vermonden, T., and Hennink, W. E. (2012). Hydrogels for protein delivery in tissue engineering. J. Control Release 161, 680-692. doi:10. 1016/j.jconrel.2012.03.002

Ceradini, D. J., and Gurtner, G. C. (2005). Homing to hypoxia: HIF-1 as a mediator of progenitor cell recruitment to injured tissue. Trends Cardiovasc. Med. 15, 57-63. doi:10.1016/j.tcm.2005.02.002

Ceradini, D. J., Kulkarni, A. R., Callaghan, M. J., Tepper, O. M., Bastidas, N., Kleinman, M. E., et al. (2004). Progenitor cell trafficking is regulated by hypoxic gradients through HIF-1 induction of SDF-1. Nat. Med. 10, 858-864. doi:10. 1038/nm1075

Champion, J. A., and Mitragotri, S. (2006). Role of target geometry in phagocytosis. Proc. Natl. Acad. Sci. U.S.A. 103, 9430-9434. doi:10.1073/pnas.0600997103

Chang, J., Liu, F., Lee, M., Wu, B., Ting, K., Zara, J. N., et al. (2013). NF- $\kappa B$ inhibits osteogenic differentiation of mesenchymal stem cells by promoting $\beta$-catenin degradation. Proc. Natl. Acad. Sci. U.S.A. 110, 9469-9474. doi:10.1073/pnas. 1300532110

Chen, G. Y., and Nunez, G. (2010). Sterile inflammation: sensing and reacting to damage. Nat. Rev. Immun. 10, 826-837. doi:10.1038/nri2873

Chi, N. H., Yang, M. C., Chung, T. W., Chen, J.-Y., Chou, N. K., and Wang, S. S. (2012). Cardiac repair achieved by bone marrow mesenchymal stem cells/silk fibroin/hyaluronic acid patches in a rat of myocardial infarction model. Biomaterials 33, 5541-5551. doi:10.1016/j.biomaterials.2012.04.030

Chirkov, S. N. (2002). The antiviral activity of chitosan. Appl. Biochem. Microbiol. 38, 5-13. doi:10.1023/A:1013206517442

Chvatal, S. A., Kim, Y. T., Bratt-Leal, A. M., Lee, H., and Bellamkonda, R. V. (2008). Spatial distribution and acute anti-inflammatory effects of methylprednisolone after sustained local delivery to the contused spinal cord. Biomaterials 29, 1967-1975. doi:10.1016/j.biomaterials.2008.01.002

Dang, T. T., Bratlie, K. M., Bogatyrev, S. R., Chen, X. Y., Langer, R., and Anderson, D. G. (2011). Spatiotemporal effects of a controlled-release anti-inflammatory drug on the cellular dynamics of host response. Biomaterials 32, 4464-4470. doi:10.1016/j.biomaterials.2011.02.048

Dang, T. T., Thai, A. V., Cohen, J., Slosberg, J. E., Siniakowicz, K., Doloff, J. C., et al. (2013). Enhanced function of immuno-isolated islets in diabetes therapy by co-encapsulation with an anti-inflammatory drug. Biomaterials 34, 5792-5801. doi:10.1016/j.biomaterials.2013.04.016

Dobaczewski, M., and Frangogiannis, N. G. (2008). Chemokines and cardiac fibrosis. Front. Biosci. (Schol Ed) 22:391-405. doi:10.1016/j.bbi.2008.05.010

Dong, Y., Eltoukhy, A. A., Alabi, C. A., Khan, O. F., Veiseh, O., Dorkin, J. R., et al. (2014). Lipid-like nanomaterials for simultaneous gene expression and silencing in vivo. Adv. Healthc. Mater. 3, 1392-1397. doi:10.1002/adhm.201400054

Ehrbar, M., Djonov, V. G., Schnell, C., Tschanz, S. A., Martiny-Baron, G., Schenk, U., et al. (2004). Cell-demanded liberation of $V_{E G F} F_{121}$ from fibrin implants induces local and controlled blood vessel growth. Circ. Res. 94, 1124-1132. doi:10.1161/01.RES.0000126411.29641.08

Friedrich, E. E., Sun, L. T., Natesan, S., Zamora, D. O., Christy, R. J., and Washburn, N. R. (2014). Effects of hyaluronic acid conjugation on anti-TNF- $\alpha$ inhibition of inflammation in burns. J. Biomed. Mater. Res. A 102, 1527-1536. doi:10.1002/ jbm.a.34829

Gadde, S., Even-Or, O., Kamaly, N., Hasija, A., Gagnon, P. G., Adusumilli, K. H., et al. (2014). Development of therapeutic polymeric nanoparticles for the resolution of inflammation. Adv. Healthc. Mater. 3, 1448-1456. doi:10.1002/ adhm. 201300688

Gao, J., Liu, R., Wu, J., Liu, Z., Li, J., Zhou, J., et al. (2012). The use of chitosan based hydrogel for enhancing the therapeutic benefits of adipose-derived MSCs for acute kidney injury. Biomaterials 33, 3673-3681. doi:10.1016/j.biomaterials. 2012.01.061

Gower, R. M., Boehler, R. M., Azarin, S. M., Ricci, C. F., Leonard, J. N., and Shea, L. D. (2014). Modulation of leukocyte infiltration and phenotype in microporous tissue engineering scaffolds via vector induced IL-10 expression. Biomaterials 35, 2024-2031. doi:10.1016/j.biomaterials.2013.11.036

Gutowski, S. M., Shoemaker, J. T., Templeman, K. L., Wei, Y., Latour, R. A., Bellamkonda, R. V., et al. (2015). Protease-degradable PEG-maleimide coating with on-demand release of IL-1Ra to improve tissue response to neural electrodes. Biomaterials 44, 55-70. doi:10.1016/j.biomaterials.2014.12.009

Helary, C., Browne, S., Mathew, A., Wang, W., and Pandit, A. (2012). Transfection of macrophages by collagen hollow spheres loaded with polyplexes: a step towards modulating inflammation. Acta Biomater. 8, 4208-4214. doi:10.1016/j.actbio. 2012.06.017

Herdrich, B. J., Danzer, E., Davey, M. G., Allukian, M., Englefield, V., Gorman, J. H., et al. (2010). Regenerative healing following foetal myocardial infarction. Eur. J. Cardiothorac. Surg. 38, 691-698. doi:10.1016/j.ejcts.2010.03.049

Hirabara, S., Kojima, T., Takahashi, N., Hanabayashi, M., and Ishiguro, N. (2013). Hyaluronan inhibits TLR-4 dependent cathepsin K and matrix metalloproteinase 1 expression in human fibroblasts. Biochem. Biophys. Res. Commun. 430, 519-522. doi:10.1016/j.bbrc.2012.12.003

Holladay, C., Power, K., Sefton, M., O'Brien, T., Gallagher, W. M., and Pandit, A. (2011). Functionalized scaffold-mediated interleukin 10 gene delivery significantly improves survival rates of stem cells in vivo. Mol. Ther. 19, 969-978. doi: $10.1038 / \mathrm{mt} .2010 .311$

Holladay, C. A., Duffy, A. M., Chen, X., Sefton, M. V., O’Brien, T. D., and Pandit, A. S. (2012). Recovery of cardiac function mediated by MSC and interleukin10 plasmid functionalised scaffold. Biomaterials 33, 1303-1314. doi:10.1016/j. biomaterials.2011.10.019

Hortensius, R. A., Becraft, J. R., Pack, D. W., and Harley, B. A. C. (2015). The effect of glycosaminoglycan content on polyethylenimine-based gene delivery within three-dimensional collagen-GAG scaffolds. Biomater. Sci. 3, 645-654. doi:10.1039/c5bm00033e

Ito, T., Fraser, I. P., Yeo, Y., Highley, C. B., Bellas, E., and Kohane, D. S. (2007). Anti-inflammatory function of an in situ cross-linkable conjugate hydrogel of hyaluronic acid and dexamethasone. Biomaterials 28, 1778-1786. doi:10.1016/j. biomaterials.2006.12.012

Jayakumar, R., Menon, D., Manzoor, K., Nair, S. V., and Tamura, H. (2010). Biomedical applications of chitin and chitosan based nanomaterials - a short review. Carbohydr. Polym. 82, 227-232. doi:10.1016/j.carbpol.2010.04.074

Jayakumar, R., Nwe, N., Tokura, S., and Tamura, H. (2007). Sulfated chitin and chitosan as novel biomaterials. Int. J. Biol. Macromol. 40, 175-181. doi:10.1016/ j.ijbiomac.2006.06.021

Je, J. Y., and Kim, S. K. (2006). Reactive oxygen species scavenging activity of aminoderivatized chitosan with different degree of deacetylation. Bioorg. Med. Chem. 14, 5989-5994. doi:10.1016/j.bmc.2006.05.016

Jiang, B., and Liao, R. (2010). The paradoxical role of inflammation in cardiac repair and regeneration. J. Cardiovasc. Transl. Res. 3, 410-416. doi:10.1007/ s12265-010-9193-7

Kajahn, J., Franz, S., Rueckert, E., Forstreuter, I., Hintze, V., Moeller, S., et al. (2012). Artificial extracellular matrices composed of collagen I and high sulfated hyaluronan modulate monocyte to macrophage differentiation under conditions of sterile inflammation. Biomatter 2, 226-236. doi:10.4161/biom.22855

Kamaly, N., Fredman, G., Subramanian, M., Gadde, S., Pesic, A., and Cheung, L. (2013). Development and in vivo efficacy of targeted polymeric inflammationresolving nanoparticles. Proc. Natl. Acad. Sci. U.S.A. 110, 6506-6511. doi:10. 1073/pnas.1303377110

Kataoka, H., Kono, H., Patel, Z., and Rock, K. L. (2014). Evaluation of the contribution of multiple DAMPs and DAMP receptors in cell death-induced sterile inflammatory responses. PLoS ONE 9:e104741. doi:10.1371/journal.pone. 0104741

Khor, E., and Lim, L. Y. (2003). Implantable applications of chitin and chitosan. Biomaterials 24, 2339-2349. doi:10.1016/S0142-9612(03)00026-7

Kim, Y. H., Furuya, H., and Tabata, Y. (2013). Enhancement of bone regeneration by dual release of a macrophage recruitment agent and platelet-rich plasma from gelatin hydrogels. Biomaterials 35, 214-224. doi:10.1016/j.biomaterials. 2013.09.103

Kim, Y. K., Que, R., Wang, S. W., and Liu, W. F. (2014). Modification of biomaterials with a self-protein inhibits the macrophage response. Adv. Healthc. Mater. 3, 989-994. doi:10.1002/adhm.201300532

Koh, T. J., and DiPietro, L. A. (2011). Inflammation and wound healing: the role of the macrophage. Expert Rev. Mol. Med. 13, 1-12. doi:10.1017/ S1462399411001943

Kraskiewicz, H., Breen, B., Sargeant, T., Mcmahon, S., and Pandit, A. (2013). Assembly of protein-based hollow spheres encapsulating a therapeutic factor ACS Chem. Neurosci. 4, 1297-1304. doi:10.1021/cn400080h 
Kulkarni, M., Loughlin, A. O., Vazquez, R., Mashayekhi, K., Rooney, P., Greiser, U., et al. (2014). Use of a fibrin-based system for enhancing angiogenesis and modulating inflammation in the treatment of hyperglycemic wounds. Biomaterials 35, 2001-2010. doi:10.1016/j.biomaterials.2013.11.003

Lee, J., Sohn, J. W., Zhang, Y., Leong, K. W., Pisetsky, D., and Sullenger, B. A. (2011). Nucleic acid-binding polymers as anti-inflammatory agents. Proc. Natl. Acad. Sci. U.S.A. 108, 14055-14060. doi:10.1073/pnas.1105777108

Leuschner, F., Dutta, P., Gorbatov, R., Novobrantseva, T. I., Donahoe, J. S., Courties, G., et al. (2011). Therapeutic siRNA silencing in inflammatory monocytes in mice. Nat. Biotechnol. 29, 1005-1010. doi:10.1038/nbt.1989

Li, J., Chen, J., and Kirsner, R. (2007). Pathophysiology of acute wound healing. Clin. Dermatol. 25, 9-18. doi:10.1016/j.clindermatol.2006.09.007

Liu, Y., Wang, L., Kikuiri, T., Akiyama, K., Chen, C., Xu, X., et al. (2011). Mesenchymal stem cell-based tissue regeneration is governed by recipient $\mathrm{T}$ lymphocytes via IFN- $\gamma$ and TNF- $\alpha$. Nat. Med. 17, 1594-1602. doi:10.1038/nm.2542

Liu, Z., Wang, H., Wang, Y., Lin, Q., Yao, A., Cao, F., et al. (2012). The influence of chitosan hydrogel on stem cell engraftment, survival and homing in the ischemic myocardial microenvironment. Biomaterials 33, 3093-3106. doi:10. 1016/j.biomaterials.2011.12.044

Lo, D. D., Zimmermann, A. S., Nauta, A., Longaker, M. T., and Lorenz, H. P. (2012). Scarless fetal skin wound healing update. Birth Defects Res. C Embryo Today 96, 237-247. doi:10.1002/bdrc.21018

Luttikhuizen, D. T., van Amerongen, M. J., de Feijter, P. C., Petersen, A. H., Harmsen, M. C., and van Luyn, M. J. A. (2006a). The correlation between difference in foreign body reaction between implant locations and cytokine and MMP expression. Biomaterials 27, 5763-5770. doi:10.1016/j.biomaterials.2006. 07.004

Luttikhuizen, D. T., Harmsen, M. C., and Van Luyn, M. J. A. (2006b). Cellular and molecular dynamics in the foreign body reaction. Tissue Eng. 12, 1955-1971. doi:10.1243/EMED_JOUR_1983_012_027_02

Mahor, S., Dash, B. C., O’Connor, S., and Pandit, A. (2012). Mannosylated polyethyleneimine-hyaluronan nanohybrids for targeted gene delivery to macrophage-like cell lines. Bioconjug. Chem. 23, 1138-1148. doi:10.1021/ bc200599k

Mantovani, A., Biswas, S. K., Galdiero, M. R., Sica, A., and Locati, M. (2013). Macrophage plasticity and polarization in tissue repair and remodelling. $J$. Pathol. 229, 176-185. doi:10.1002/path.4133

Martin, P., and Leibovich, S. J. (2005). Inflammatory cells during wound repair: the good, the bad and the ugly. Trends Cell Biol. 15, 599-607. doi:10.1016/j.tcb.2005. 09.002

Monaghan, M., and Pandit, A. (2011). RNA interference therapy via functionalized scaffolds. Adv. Drug Deliv. Rev. 63, 197-208. doi:10.1016/j.addr.2011.01.006

Mosser, D. M., and Edwards, J. P. (2009). Exploring the full spectrum of macrophage activation. Genetics 8, 958-969. doi:10.1038/nri2448

Mountziaris, P. M., Tzouanas, S. N., Sing, D. C., Kramer, P. R., Kurtis Kasper, F., and Mikos, A. G. (2012). Intra-articular controlled release of antiinflammatory siRNA with biodegradable polymer microparticles ameliorates temporomandibular joint inflammation. Acta Biomater. 8, 3552-3560. doi:10. 1016/j.actbio.2012.06.031

Muscari, C., Bonafè, F., Martin-Suarez, S., Valgimigli, S., Valente, S., Fiumana, E., et al. (2013). Restored perfusion and reduced inflammation in the infarcted heart after grafting stem cells with a hyaluronan-based scaffold. J. Cell. Mol. Med. 17, 518-530. doi:10.1111/jcmm.12039

Nakamura, K., Yokohama, S., Yoneda, M., Okamoto, S., Tamaki, Y., Ito, T., et al. (2004). High, but not low, molecular weight hyaluronan prevents Tcell-mediated liver injury by reducing proinflammatory cytokines in mice. $J$. Gastroenterol. 39, 346-354. doi:10.1007/s00535-003-1301-x

O'Rorke, S., Keeney, M., and Pandit, A. (2010). Non-viral polyplexes: scaffold mediated delivery for gene therapy. Prog. Polym. Sci. 35, 441-458. doi:10.1016/ j.progpolymsci.2010.01.005

Park, J. S., Yang, H. N., Jeon, S. Y., Woo, D. G., Kim, M. S., and Park, K. H. (2012). The use of anti-COX2 siRNA coated onto PLGA nanoparticles loading dexamethasone in the treatment of rheumatoid arthritis. Biomaterials 33, 8600-8612. doi:10.1016/j.biomaterials.2012.08.008

Park, S., Kang, S., Chen, X., Kim, E. J., Kim, J., Kim, N., et al. (2013). Tumor suppression via paclitaxel-loaded drug carriers that target inflammation marker upregulated in tumor vasculature and macrophages. Biomaterials 34, 598-605. doi:10.1016/j.biomaterials.2012.10.004
Prabaharan, M. (2008). Review paper: chitosan derivatives as promising materials for controlled drug delivery. J. Biomater. Appl. 23, 5-36. doi:10.1177/ 0885328208091562

Présumey, J., Salzano, G., Courties, G., Shires, M., Ponchel, F., Jorgensen, C., et al. (2012). PLGA microspheres encapsulating siRNA anti-TNFalpha: efficient RNAi-mediated treatment of arthritic joints. Eur. J. Pharm. Biopharm. 82, 457-464. doi:10.1016/j.ejpb.2012.07.021

Ratanavaraporn, J., Furuya, H., and Tabata, Y. (2012). Local suppression of proinflammatory cytokines and the effects in BMP-2-induced bone regeneration. Biomaterials 33, 304-316. doi:10.1016/j.biomaterials.2011.09.050

Redd, M. J., Cooper, L., Wood, W., Stramer, B., and Martin, P. (2004). Wound healing and inflammation: embryos reveal the way to perfect repair. Philos. Trans. R Soc. Lond. B Biol. Sci. 359, 777-784. doi:10.1098/rstb.2004.1466

Rodriguez, P. L., Harada, T., Christian, D. A., Pantano, D. A., Tsai, R. K., and Discher, D. A. (2013). Minimal "self" peptides that inhibit phagocytic clearance and enhance delivery of nanoparticles. Science 339, 971-975. doi:10.1126/science. 122956

Sehgal, P. K., and Srinivasan, A. (2009). Collagen-coated microparticles in drug delivery. Expert Opin. Drug Deliv. 6, 687-695. doi:10.1517/17425240903025736

Seliktar, D. (2012). Designing cell-compatible hydrogels. Science 336, 1124-1129. doi:10.1126/science.1214804

Seshadri, G., Sy, J. C., Brown, M., Dikalov, S., Yang, S. C., Murthy, N., et al. (2010). The delivery of superoxide dismutase encapsulated in polyketal microparticles to rat myocardium and protection from myocardial ischemia-reperfusion injury. Biomaterials 31, 1372-1379. doi:10.1016/j.biomaterials.2009.10.045

Shah, P. P., Desai, P. R., Patel, A. R., and Singh, M. S. (2012). Skin permeating nanogel for the cutaneous co-delivery of two anti-inflammatory drugs. Biomaterials 33, 1607-1617. doi:10.1016/j.biomaterials.2011.11.011

Singh, A., Agarwal, R., Diaz-Ruiz, C. A., Willett, N. J., Wang, P., Lee, L. A., et al. (2014). Nanoengineered particles for enhanced intra-articular retention and delivery of proteins. Adv. Healthc. Mater. 3, 1562-1567. doi:10.1002/adhm. 201400051

Singh, A., Nie, H., Ghosn, B., Qin, H., Kwak, L. W., and Roy, K. (2008). Efficient modulation of T-cell response by dual-mode, single-carrier delivery of cytokinetargeted siRNA and DNA vaccine to antigen-presenting cells. Mol. Ther. 16, 2011-2021. doi:10.1038/mt.2008.206

Spiller, K. L., Anfang, R. R., Spiller, K. J., Ng, J., Nakazawa, K. R., Daulton, J. W., et al. (2014). The role of macrophage phenotype in vascularization of tissue engineering scaffolds. Biomaterials 35, 4477-4488. doi:10.1016/j.biomaterials. 2014.02.012

Su, J., Hu, B. H., Lowe, W. L., Kaufman, D. B., and Messersmith, P. B. (2010). Antiinflammatory peptide-functionalized hydrogels for insulin-secreting cell encapsulation. Biomaterials 31, 308-314. doi:10.1016/j.biomaterials.2009.09.045

Sy, J. C., Seshadri, G., Yang, S. C., Brown, M., Oh, T., Dikalov, S., et al. (2008). Sustained release of a p38 inhibitor from non-inflammatory microspheres inhibits cardiac dysfunction. Nat. Mater. 7, 863-868. doi:10.1038/nmat2299

Thevenot, P. T., Nair, A. M., Shen, J., Lotfi, P., Ko, C. Y., and Tang, L. (2010). The effect of incorporation of SDF-1 $\alpha$ into PLGA scaffolds on stem cell recruitment and the inflammatory response. Biomaterials 31, 3997-4008. doi:10.1016/j. biomaterials.2010.01.144

van Putten, S. M., Ploeger, D. T. A., Popa, E. R., and Bank, R. A. (2013). Macrophage phenotypes in the collagen-induced foreign body reaction in rats. Acta Biomater. 9, 6502-6510. doi:10.1016/j.actbio.2013.01.022

van Putten, S. M., Wübben, M., Hennink, W. E., van Luyn, M. J. A., and Harmsen, M. C. (2009). The downmodulation of the foreign body reaction by cytomegalovirus encoded interleukin-10. Biomaterials 30, 730-735. doi:10. 1016/j.biomaterials.2008.10.043

Wang, Q. S., Cui, Y. L., Gao, L. N., Guo, Y., Li, R. X., and Zhang, X. Z. (2014a) Reduction of the pro-inflammatory response by tetrandrine-loading poly(llactic acid) films in vitro and in vivo. J. Biomed. Mater. Res. A 102A, 4098-4107. doi:10.1002/jbm.a.35083

Wang, W., Sun, L., Zhang, P., Song, J., and Liu, W. (2014b). An anti-inflammatory cell-free collagen/resveratrol scaffold for repairing osteochondral defects in rabbits. Acta Biomater. 10, 4983-4995. doi:10.1016/j.actbio.2014.08.022

Webber, M. J., Matson, J. B., Tamboli, V. K., and Stupp, S. I. (2012). Controlled release of dexamethasone from peptide nanofiber gels to modulate inflammatory response. Biomaterials 33, 6823-6832. doi:10.1016/j.biomaterials. 2012.06.003 
Whitmire, R. E., Wilson, D. S., Singh, A., Levenston, M. E., Murthy, N., and García, A. J. (2012). Self-assembling nanoparticles for intra-articular delivery of antiinflammatory proteins. Biomaterials 33, 7665-7675. doi:10.1016/j.biomaterials. 2012.06 .101

Wynn, T. A., and Barron, L. (2010). Macrophages: master regulators of inflammation and fibrosis. Semin. Liver Dis. 30, 245-257. doi:10.1055/s-0030- 1255354

Xia, Z., and Triffitt, J. T. (2006). A review on macrophage responses to biomaterials. Biomed. Mater. 1, R1-R9. doi:10.1088/1748-6041/1/1/R01

Yoshitomi, T., and Nagasaki, Y. (2014). Reactive oxygen species-scavenging nanomedicines for the treatment of oxidative stress injuries. Adv. Healthc. Mater. 3, 1149-1161. doi:10.1002/adhm.201300576

Yuan, Z., Zhao, J., Zhu, W., Yang, Z., Li, B., Yang, H., et al. (2014). Ibuprofenloaded electrospun fibrous scaffold doped with sodium bicarbonate for responsively inhibiting inflammation and promoting muscle wound healing in vivo. Biomater. Sci. 2, 502-511. doi:10.1039/c3bm60198f

Zachman, A. L., Crowder, S. W., Ortiz, O., Zienkiewicz, K. J., Bronikowski, C. M., Yu, S. S., et al. (2012). Pro-angiogenic and anti-inflammatory regulation by functional peptides loaded in polymeric implants for soft tissue regeneration. Tissue Eng. Part A 19, 437. doi:10.1089/ten.tea.2012.0158

Zhang, D., Wei, Y., Chen, K., Zhang, X., Xu, X., and Shi, Q. (2015). Biocompatible reactive oxygen species (ROS)-responsive nanoparticles as superior drug delivery vehicles. Adv. Healthc. Mater. 4, 69-76. doi:10.1002/adhm. 201400299

Zhang, J., Tang, C., and Yin, C. (2013). Galactosylated trimethyl chitosan-cysteine nanoparticles loaded with Map4k4 siRNA for targeting activated macrophages. Biomaterials 34, 3667-3677. doi:10.1016/j.biomaterials.2013.01.079

Zisch, A. H., Lutolf, M. P., Ehrbar, M., Raeber, G. P., Rizzi, S. C., Davies, N., et al. (2003). Cell-demanded release of VEGF from synthetic, biointeractive cell ingrowth matrices for vascularized tissue growth. FASEB J. 17, 2260-2262. doi:10.1096/fj.02-1041fje

Conflict of Interest Statement: The authors declare that the research was conducted in the absence of any commercial or financial relationships that could be construed as a potential conflict of interest.

Copyright $\odot 2015$ Browne and Pandit. This is an open-access article distributed under the terms of the Creative Commons Attribution License (CC BY). The use, distribution or reproduction in other forums is permitted, provided the original author(s) or licensor are credited and that the original publication in this journal is cited, in accordance with accepted academic practice. No use, distribution or reproduction is permitted which does not comply with these terms. 